\title{
Predictive Relationships Among Smartphone Addiction, Fear of Missing Out and Interaction Anxiousness
}

\author{
Cagla Girgin Buyukbayraktar \\ Selcuk University, Turkey
}

Doi:10.19044/ejes.v7no2a1 URL:http://dx.doi.org/10.19044/ejes.v7no2a1

\begin{abstract}
The aim of this study is to reveal the predictive relationships among smartphone addiction, fear of missing out (FOMO) and interaction anxiousness in university students. The study group of the research consists of 610 university students, $325(53.3 \%)$ females and 285 (46.7\%) males that were studying in Konya Turkey. In order to collect the data scales of Smartphone Addiction, Fearing Missing Developments in Social Environments and Interaction Anxiousness were used. The data were analyzed according to the "Structural Equation Model" via the AMOS program. According to the findings, the fear of missing out affects smartphone addiction significantly. Fearing of missing developments in social environments significantly affects interaction anxiousness and the interaction anxiousness meaningfully affects smartphone addiction.
\end{abstract}

Keywords: Smartphone addiction, FOMO, Interaction Anxiousness, University students.

\section{Introduction}

Smartphones are increasingly ubiquitous (Andrus, Dall, Hof, Laadan $\&$ Nieh, 2011) and offer a wide range of mobile applications for information, communication, education and entertainment (Haugi et al., 2015). While it is clear that people have the general tendency to be concerned about selfpresentation and interaction with others, the underlying causes of such a predisposition are unclear and possibly complex (Auera, Calvia, Jordana, Schradera \& Byrd-Cravena, 2018). It is observed that individuals experience more anxiety in social environments than they do when they are alone (Coskun, 2009).

Smartphones have replaced not only cell phones, but also personal computers and many other devices. Large screen sizes and natural mobility have enabled access to many functions anytime and anywhere (Samaha \& 
Hawi, 2016). In addition to these advantages, due to the fact that smartphones allow the use of many features of the internet, it has emerged that addiction to smart phones causes physical and psychosocial problems (O'Reilly, 1996). Excessive smartphone usage causes a decrease in real life social interaction (Kuss \& Griffiths, 2011). Adolescents with poor social competence who are concerned about social interactions find social interactions online less dangerous than real life because of the anonymity provided by the internet (Shin \& Jang, 2016). For this reason, according to Bonetti, Campbell \& Gilmore (2010), with the widespread use of the Internet, the behavior of individuals' behaviors of establishing and maintaining friendships have begun to be moved to the virtual environment. Based on this situation, technological dependence is significantly more common in young adults (18-30 years old) who are in constant communication via new technologies (Laconi, Tricard \& Chabrol, 2015).

The fact that information is more accessible than ever, since many people can now access social media on mobile devices, has made it possible for people to become more dependent on consuming information. Social media gives people the opportunity to share information with others easily and allows them to manipulate what other people are doing and saying (Abel, Buff \& Burr, 2016; Hetz, Dawson \& Cullen, 2015). With this opportunity and with the fear of missing out on social developments, frequent use of internet communication applications can trigger the behavior of following other users' online activities (Wegmanna, Oberst, Stodt \& Branda, 2017). The FOMO experience has been made possible by the virtual explosion of real-time sharing provided by social media tools, smartphones and tablets. These tools provide a continuous opportunity to influence what others are missing. While these technological facilities allow more frequent social interaction, they also increase the dependence of trust on mediated communication (Conlin, Billings \& Averset, 2016).

Social interaction anxiousness means experiencing anxiety about social situations involving significant direct social interaction with others, such as meeting someone new at a party, talking to an attractive person or expressing views (Kimbrel, Mitchell \& Nelson-Gray, 2010). It is at this point that individuals who prefer to communicate with others indirectly, due to the anxiety they experience, are likely to experience the fear of missing out and become dependent on smartphones. Therefore, in this study, it was aimed to reveal the predictive relationships among smartphone addiction, fear of missing out (FOMO) and interaction anxiousness in university students. 


\section{Smartphone addiction}

Smartphone addiction is defined as the compulsion to use smartphones, even though individuals can anticipate the risks and negative consequences of their behavior (Kim, Lee, Lee, Nam \& Chung, 2014). Smartphone addiction is characterized by symptoms of compulsive behavior, withdrawal, tolerance and functional deterioration (Lopez-Fernandez, 2017) as an impulse control disorder (Park \& Lee, 2011; Mok et al., 2014). Besides, according to Jeong, Kim, Yum \& Hwang (2016), social networking and playing games are also avenues of smartphone addiction. Smartphones have become the basic devices in daily life; however, the technological advantages of smartphones cause adverse side effects when used excessively (Kim, 2013; Kuss, Griffiths, Karila \& Billieux, 2014). Smartphone addiction may be accompanied by anxiety (Hawi \& Samaha, 2017a; Elhai, Levine \& Hall, 2019), low life satisfaction (Hawi \& Samaha, 2017b), and reduced psychosocial well-being (Herrero, Urueña, Torres \& Hidalgo, 2019).

\section{FoMO (Fear of Missing out)}

Fear of missing out (FOMO) developments may indicate a certain personal inclination and a certain cognition about FOMO in an online topic (Fox \& Moreland, 2015). According to Przybylski, Murayama, DeHaan and Gladwell (2013), the fear of missing out is the fear that other people will have fun without you.

It seems that those who are afraid of missing out on social happenings use social media extensively because they feel that they need to be constantly aware of everything that is happening in their social networks as a means of their basic satisfaction needs (Przybylski, Murayama, DeHaan \& Gladwell, 2013). Social media use can only be one result of FOMO. The ones who have high FOMO and who are staying connected with others can be affected negatively in terms of their mental and physical health (Baker, Krieger \& LeRoy, 2016).

\section{The Interaction Anxiousness}

Although social anxiety is seen as a unified theory, there are subcategories of social anxiety, such as the fear can be limited to a particular situation or it can be generalized and show up in many situations. Attempts to classify the causes of anxiety distinguish between those involving others observing or examining them, and those involving social interactions such as speaking or greeting (Liebowitz, 1987, quoted by Habke, Hewitt, Norton \& Asmundson, 1997). Accordingly, social and social interaction anxiousness can be divided into two categories: general fear of social interaction situations/social phobia, and fear of being socially examined during routine 
activities (Lyvers, Hanigan \& Thorberg, 2018). Social interaction anxiousness is defined as individuals' anxiety in different social environments (Leary \& Kowalski, 1993), meeting with others, fear and avoidance of interaction and self-expression (Kashdan, 2004). Disturbing emotions are among the main symptoms of social interaction anxiousness (Pierce, 2009), which is also defined as meeting other people and having trouble in speaking with them (Mattick \& Clarke, 1998). Individuals with social interaction anxiousness tend to be self-conscious and criticize themselves more during social experiences (Hirsch, Clark, Mathews \& Williams, 2003). The interaction anxiousness scale used in this study is also important in terms of emphasizing the emotional element of social tension (Coskun, 2009).

Individuals who prefer to communicate with others indirectly, due to the anxiety they experience, are likely to experience the fear of missing out and become dependent on smartphones. At this point, it was aimed to reveal the predictive relationships among smartphone addiction, fear of missing out (FOMO) and interaction anxiousness in university students.

\section{Method}

In the research, it was aimed to test the model that was formed with relationship among the fear of missing out, interaction anxiousness and smartphone addiction. For this purpose, the relational survey model, which is a sub-type of the general survey model, was used. Relational survey model is the research conducted to determine the relationships between two or more variables (Buyukozturk, Kilic-Cakmak, Akgun, Karadeniz \& Demirel, 2014).

\section{Study Group}

The study group of the research was formed with university students in the province of Konya in Turkey who volunteered to participate in the study. The study group consisted of 325 (53.3\%) females and 285 (46.7\%) males, for a total of 610 subjects. There were 185 students (30.3\%) between the ages of $18-20,262(43.0 \%)$ between the ages of $21-23$ and $163(26.7 \%)$ over the age of 24 . According to their years of study, there were $96(15.7 \%)$ freshmen, there were $226(37.0 \%)$ students who were in their second year, there were 149 people $(24.4 \%)$ who were in their third year and $139(22.8 \%)$ in their final year.

\section{Data Collection Tools \\ The Fear of Missing Out scale (FOMOs)}

In order to measure students' fears of missing out on social happenings, the Fear of Missing Out scale (FOMOS) developed by Przybylski, Murayama, DeHaan \& Gladwell (2013) was used in the research. The high score obtained from the scale, consisting of 10 items and a five-point Likert type, shows that 
the fear of missing is increased. The reliability and validity studies of the scale in Turkey was carried out by Gokler, Aydin, Unal \& Metintas (2016). According to the factor analysis, the factor loads of the one-dimensional structure vary between $0.36-0.77$. Cronbach alpha coefficient of the scale was found 0.81 , and the test-retest reliability coefficient was 0.81 (Gokler, Aydin, Unal \& Metintas, 2016). The Cronbach alpha coefficient calculated in this research was found as .83. Cronbach's alpha $(\alpha)$ coefficient is used to estimate the reliability of a psychometric test. If the coefficient is 0.7 and above, the reliability of the scale is considered good (Kilic, 2016).

\section{The Social Interaction Anxiousness Scale (SIAS):}

In order to measure students' interaction anxiety levels in the research, the Interaction Anxiousness Scale developed by Leary and Kowalski (1993) was used. The high score of the scale consisting of 15 items and a five-point Likert type indicates the high level of interaction anxiousness and the low score display low level of interaction anxiousness. In the studies conducted by Leary and Kowalski (1993), the internal consistency of the scale was reported as .88 and the test-retest reliability coefficient was .80 . The validity and reliability studies of the Turkish sample were conducted Coskun (2009). The results of the various factor analyzes show that the items of the scale are gathered in a single factor, consistent with the original scale, and explain $44.4 \%$ of the variance. The internal consistency coefficient of the scale was found to be .91 and the test-retest reliability coefficient performed at threeweek intervals was .80 (Coskun, 2009). The Cronbach alpha coefficient calculated in this research was .65. Cronbach's alpha $(\alpha)$ coefficient is used to estimate the reliability of a psychometric test. If the coefficient is 0.7 and above, the reliability of the scale is considered good (Kilic, 2016).

\section{Smartphone Addiction Scale Short Form:}

In order to measure students' smartphone addiction in the research, the Smartphone Addiction scale developed by Kwon et al. (2013) was used. The high score obtained from the 10-item Likert-type scale shows that smartphone addiction is high. In the studies conducted by Kwon et al. (2013), the Cronbach alpha values of the scale was reported as .96. Reliability and validity studies of the scale were carried out by Noyan, Enez-Darcin, Nurmedov, Yilmaz \& Dilbaz (2015) in Turkey. Cronbach alpha coefficient, which shows the reliability of the scale, was measured as 0.867. Test-retest reliability coefficient was found to be 0.926 (Noyan, Enez-Darcin, Nurmedov, Yilmaz \& Dilbaz, 2015). Cronbach alpha coefficient calculated in this research is found as .87. Cronbach's alpha $(\alpha)$ coefficient is used to estimate the reliability of a psychometric test. If the coefficient is 0.7 and above, the reliability of the scale is considered good (Kilic, 2016). 


\section{Data Analysis}

In this study, which was conducted to test the model formed with the predictive relationships among smartphone addiction, fear of missing out (FOMO) and interaction anxiety in university students, the correlation values of variables were obtained via SPSS 21 program. Then, the model formed was tested with Structural Equation Model (SEM). SEM is a method performed to establish a statistical cause-effect bond (Byrene, 2013). Since each of the scales in the model consists of a single dimension, it reduces the standard errors in the measurement and increases the reliability (Alhija \& Wisenbaker, 2006). Each scale is divided into two parcels, taking into account their internal consistency. Parceling is computing sums or average scores across multiple items. They are used as indicators of latent factors in the structural equation modeling. The model obtained in the present study was tested with the AMOS 16 program.

\section{Results}

In this section, correlation analysis for the relationships among the variables and findings of the structural equation model are presented.

\section{Correlation Values Between Variables}

Table 1. Correlation Table Among Fear of Missing Out, Interaction Anxiousness and Smartphone Addiction

\begin{tabular}{llll}
\hline Analyse & \multicolumn{2}{l}{ Fear of MissingInteraction } & $\begin{array}{l}\text { Smartphone } \\
\text { Out }\end{array}$ \\
\hline Fear of Missing Out & Anxiousness & Addiction \\
Interaction & $.356^{* *}$ & $.496^{* *}$ \\
Anxiousness & 1 & $.306^{* *}$ \\
$\begin{array}{l}\text { Smartphone } \\
\text { Addiction }\end{array}$ & & 1 \\
\hline
\end{tabular}

According to the findings in Table 1, positive correlations were found. These correlations are as follows: between fear of missing out and smartphone addiction $(\mathrm{r}=.496, \mathrm{p}<.01)$; between interaction anxiousness and smartphone addiction $(\mathrm{r}=.306, \mathrm{p}<.01)$ and between fear of missing out and interaction anxiousness $(\mathrm{r}=.356, \mathrm{p}<.01)$. 


\section{Structural Equation Model}

The effect of fear of missing out on interaction anxiousness and smartphone addiction and the effect of interaction anxiousness on smartphone addiction were tested via the Structural Equation Model. Each of the paths shown in the model was found statistically significant. It was observed that the fit indices of the model obtained showed a good fit.

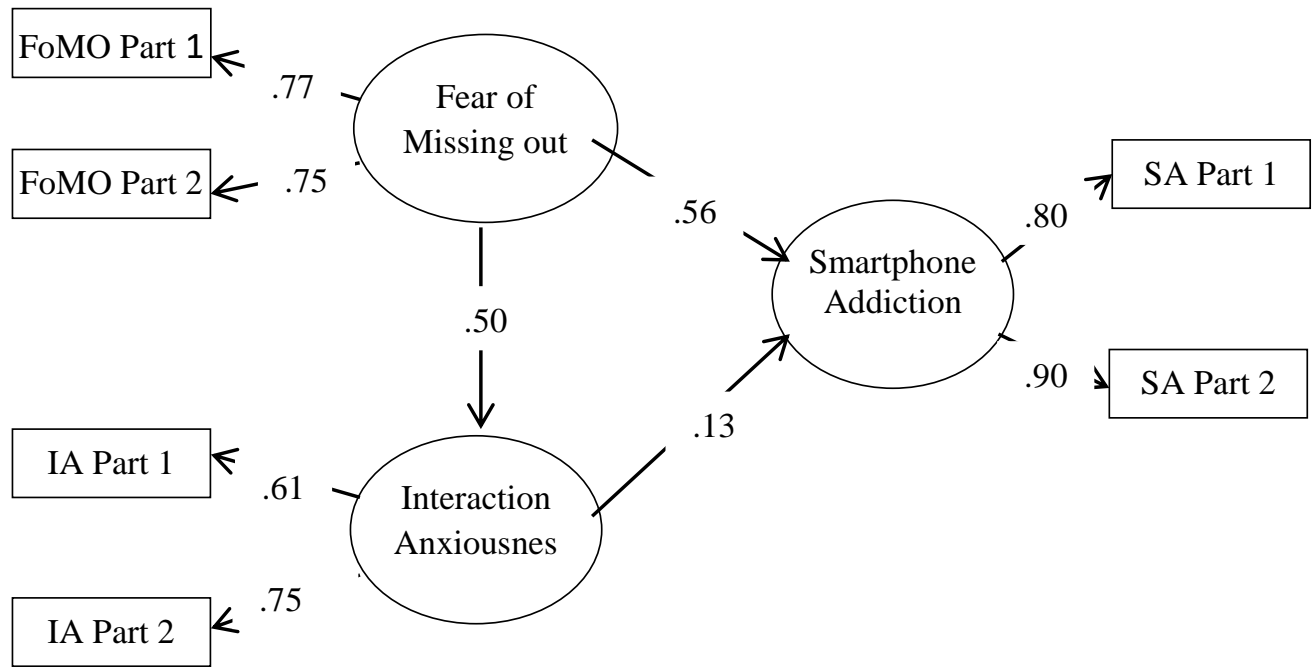

Figure 1. Structural Equation Model Test Results

Note. ${ }^{*} \mathrm{p}<0.01$, FoMO Part 1-2= Fear of missing out parcel, SA Part 1$2=$ Smartphone addiction parcel, parcel

When the fit values of the model in Figure 1 are examined, the following results were obtained: $\mathrm{X}^{2} / \mathrm{sd}=1.98, \mathrm{RMSEA}=0.04$, SRMR $=0.0$, AGFI $=0.98$, NFI $=0.99$, GFI $=0.99$, CFI $=0.99$, TLI $=0.98$. In general, it is understood that the model has the desired level of fit (Bollen, 1989; Browne \& Cudeck, 1993; Byrne, 2010; Hu \& Bentler, 1999; Kline, 2011; Tanaka \& Huba, 1985). The one-factor model tested is shown in Figure 1. All paths shown in the model are significant at 0.001 level. These values show that the established structural model is within acceptable limits. The standardized beta, standard error and significance values of the model are shown in Table 2. 
Table 2. Model for Predictive Relationships Among Fear of Missing Out, Interaction Anxiousness and Smartphone Addiction

\begin{tabular}{|c|c|c|c|c|}
\hline $\begin{array}{l}\text { Predictive } \\
\text { Variable }\end{array}$ & Dependent Variable & $\begin{array}{l}\text { Standardized } \\
\beta\end{array}$ & $\begin{array}{l}\text { Standard } \\
\text { Error }\end{array}$ & $\begin{array}{l}\text { Critic } \\
\text { Value }\end{array}$ \\
\hline $\begin{array}{l}\text { Fear of Missing } \\
\text { Out }\end{array}$ & $\begin{array}{l}\text { Smartphone } \\
\text { Addiction }\end{array}$ & 0.56 & 0.09 & $8.29 * *$ \\
\hline $\begin{array}{l}\text { Fear of Missing } \\
\text { Out }\end{array}$ & $\begin{array}{l}\text { Interaction } \\
\text { Anxiousness }\end{array}$ & 0.50 & 0.06 & $8.08 * *$ \\
\hline $\begin{array}{l}\text { Interaction } \\
\text { Anxiousness }\end{array}$ & $\begin{array}{l}\text { Smartphone } \\
\text { Addiction }\end{array}$ & 0.13 & 0.07 & $2.11 *$ \\
\hline
\end{tabular}

The connection coefficient value for this factor was found to be $\beta=0.56$. Fear of missing out significantly affects interaction anxiousness and interaction anxiety affects smartphone addiction meaningfully. Connection coefficients obtained were respectively $\beta=0.50$ and $\beta=0.13$. A positive effect was observed on all paths of the model.

\section{Discussion}

According to the findings, the fear of missing out (FoMO) affects smartphone addiction significantly. This finding supports the effect of FoMO on the overuse of smartphones obtained in previous studies (Elhai, Levine, Dvorak \& Hall, 2016; Chotpitayasunondh \& Douglas, 2016; Clayton, Leshner \& Almond, 2015; Hong, Chiu \& Huang, 2012). Individuals experiencing high levels of FoMO are likely to suffer from problematic smartphone usage and emotional control (Wolniewicz, Tiamiyu, Weeks \& Elhai, 2018). In addition, there is a significant relationship between addiction to the internet and social networks and the excessive usage of the smartphones (Mohammadi et al., 2018). Most smartphone users utilize the internet at high levels (Kawabe, Horiuchi, Ochi, Oka \& Uenno, 2016). One of the most important channels of communication with people is through the internet, and social networks help people to be aware of what is happening around the world. Thus, avoiding the flow of information can give the person a feeling that one of their life channels has disappeared. Therefore the individual can reach for their smartphone as a means to stay informed and avoid this feeling. In addition, the positive relationship between FoMO and internet addiction support the findings of the study (Blanca \& Bendayan, 2018). FoMO has been associated with problematic internet use, especially the overuse of social media (Alt, 2015; Casalea, Rugaib \& Fioravantia, 2018).

Fear of missing out significantly affects interaction anxiousness. The fear of missing out is a triggering factor for people as the grasp for being aware of what is going on (Reagle, 2015), as well as the use of social media 
(Przybylski, Murayama, DeHaan \& Gladwell, 2013; Oberst, Wegmann, Stodt, Brand \& Chamarro, 2017). People with interaction anxiousness are those who avoid being in face-to-face social environments and prefer mediated social relationships. Based on this, it is possible that a person who continues to communicate via the internet and waits to be informed about people minuteby-minute, will have anxiety when interacting with others. Social anxiety (Dempseya, O'Briena, Tiamiyua \& Elhaia, 2019) is associated with fear of missing out on social happenings. The findings of the studies in the field (Elhai, Levine, Alghraibeh, Alafnan, Aldraiweesh \& Hall, 2018; Elhaia, Yanga, Fanga, Baia \& Hall, 2019) supports the findings of the present study regarding FoMO mediating the relationships between smartphone addiction and interaction anxiousness.

Interaction anxiousness significantly affects smartphone addiction. In studies conducted on the subject, smartphone addiction was found to be significantly associated with anxiety (Billieux et al. 2015; Thomsen et al., 2018). The convenience of the smartphone keeps the person in contact with other people without feeling threatened by uncomfortable emotions. For this reason, individuals with social anxiety tend to communicate with other people via their smartphones. The more the individual avoids communicating directly, the higher the anxiety of interaction can be, and the higher the frequency of smartphone usage. A statistically significant positive relationship was found between interaction anxiety and smartphone addiction among university students (Konan, Durmus, Turkoglu \& Agiroglu-Bakir, 2018; Konan \& Celik, 2019). There were similar results in the research conducted by Lee, Chang, Lin, \& Cheng (2014). These findings support the findings obtained in the present study.

\section{Conclusion}

As a result of the study, it was found that the fear of missing out, smartphone addiction and interaction anxiousness were significantly related in university students. Additionally, the model among the variables was found to be significant. It is obvious that university students are at an important transition period in their lives. In this period, considering the risky behavior characteristics of the age range they are in, they may tend to suffer more from smartphone addiction. As they step into new social environments, they might feel anxious while communicating with people-this can easily be triggered in a university environment where they meet new people regularly. Therefore, instead of sitting, talking, traveling and communicating directly with them, they can make smartphones the easiest way to reach and be informed about these new friends. As a result, fear of missing out in university students, increases smartphone addiction, and is likely to be found in young people who have interaction anxiousness. 


\section{Recommendations}

According to the results obtained in the study, due to their developmental characteristics, university students might want to be aware of their friends' environment and what is happening in the world. This can push them to worry about being unaware of what's happening in their social environment. At the same time, young people who develop such anxiety can turn into individuals who avoid communicating face-to-face with people and instead prefer smartphone-mediated interactions, which is a potential danger for young people. Young people can and should be directed to social environments where they can have fun through face-to-face communication. Being in youth groups and participating in volunteering activities may help them work through their potential concerns. This may help them fulfill their needs of belonging to a group. At the same time, young people can be informed about to what extent the use of smart phones is necessary, as well as what kind of usage makes it problematic. The limitations imposed on the students in the necessary environments may also boost them in conscious usage of smartphones.

\section{Acknowledgements or Notes}

I would like to thank Dr. Banu Uslu for her support in translation and the lifelong courage as a friend.

\section{References}

1. Abel, J. P., Buff, C. L., \& Burr, S. A. (2016). Social media and the fear of missing out: Scale development and assessment. Journal of Business \& Economics Research-First Quarter, 14(1), 33-44.

2. Alhija, F. N. A., \& Wisenbaker, J. (2006). A Monte Carlo study investigating the impact of item parceling strategies on parameter estimates and their standard errors in CFA. Structural Equation Modeling: A Multidisciplinary Journal, 13(2), 204-228. https://doi.org/10.1207/s15328007sem1302_3

3. Alt, D. (2015). College students' academic motivation, media engagement and fear of missing out. Computers in Human Behavior, 49, 111-119.

4. Andrus, J., Dall, C., Hof, A.V., Laadan, O., \& Nieh, J. (2011). Cells: A virtual mobile smartphone architecture. SOSP '11: Proceedings of the Twenty-Third ACM Symposium on Operating Systems Principles October 173-187 https://doi.org/10.1145/2043556.2043574

5. Auera, B. J., Calvia, J. L., Jordana, N.M., Schradera, D., \& ByrdCravena, J. (2018). Communication and social interaction anxiety enhance interleukin-1 beta and cortisol reactivity during high-stakes 
public speaking. Psychoneuroendocrinology, 94, 83-90. https://doi.org/10.1016/j.psyneuen.2018.05.011

6. Baker, Z. G., Krieger, H. \& LeRoy, A. S. (2016). Fear of missing out: Relationships with depression, mindfulness, and physical symptoms. Translational Issues in Psychological Science, 2(3), 275-282.

7. Billieux, J., Philippot, P., Schmid, C., Maurage, P., Mol, J. D., \& Linden, M. V. D. (2015). Is dysfunctional use of the mobile phone a behavioral addiction? Confronting symptom-based versus processbased approaches. Clinical Psychology \& Psychotherapy, 22(5), 460468. https://doi.org/10.1002/cpp.1910

8. Blanca, M. J. \& Bendayan, R. (2018). Spanish version of the Phubbing Scale: Internet addiction, Facebook intrusion, and fear of missing out as correlates. Psicothema, 30(4), 449-454 doi: 10.7334/psicothema2018.153

9. Bollen, K. A. (1989). Structural equations with latent variables. New York: John Wiley \& Sons, Inc.

10. Bonetti, L., Campbell, M. A., \& Gilmore, L. (2010). The relationship of loneliness and social anxiety with children's and adolescents' online communication. Cyberpsychology, Behavior and Social Networking, 13(3), 279-285.

11. Browne, M. W., \& Cudeck, R. (1993). Alternative ways of assessing model fit. In K. A. Bollen and J. S. Long (Eds.), Testing structural equation models (pp. 136-162). Newbury Park, CA: Sage.

12. Buyukozturk, S., Kilic-Cakmak, E., Akgun, E.O., Karadeniz, S., \& Demirel, F. (2014). Scientific research methods. Ankara: Pegem Academy Publishing.

13. Byrne, B. M. (2010). Structural equation modeling with AMOS: Basic concepts, applications, and programming. 2nd Edition. Routledge Taylor \& Francis Group.

14. Casalea, S., Rugaib, L., \& Fioravantia, G. (2018). Exploring the role of positive metacognitions in explaining the association between the fear of missing out and social media addiction. Addictive Behaviors, 85, 83-87.

15. Chotpitayasunondh, V., \& Douglas, K. M. (2016). How "phubbing" becomes the norm: The antecedents and consequences of snubbing via smartphone. Computers in Human Behavior, 63, 9-18. http://dx.doi.org/10.1016/j.chb.2016.05.018.

16. Clayton, R. B., Leshner, G., \& Almond, A. (2015). The extended iSelf: the impact of iPhone separation on cognition, emotion, and physiology. Journal of Computer-Mediated Communication, 20, 119135. http://dx.doi.org/10.1111/jcc4.12109 
17. Conlin, L., Billings, A. C. \& Averset, L. (2016). Time-shifting vs. appointment viewing: the role of fear of missing out within TV consumption behaviors. Communication \& Society, 29(4), 151-164.

18. Coskun, H. (2009). The interaction anxiousness scale: A study for validity and reliability. Türk Psikoloji Yazllarl, 12(23), 41-49.

19. Dempseya, A. E., O'Briena, K.D., Tiamiyua, M.F. \& Elhaia, J. D. (2019). Fear of missing out (FoMO) and rumination mediate relations between social anxiety and problematic Facebook use. Addictive Behaviors Reports, 9, 100-150.

20. Elhai, J. D., Levine, J. C., Alghraibeh, A. M., Alafnan, A., Aldraiweesh, A. A. \& Hall, B. J. (2018). Fear of missing out: Testing relationships with negative affectivity, online social engagement, and problematic smartphone use. Computers in Human Behavior, 89, 289298. https://doi.org/10.1016/j.chb.2018.08.020.

21. Elhai, J. D., Levine, J. C., Dvorak, R. D. \& Hall, B. J. (2016). Fear of missing out, need for touch, anxiety and depression are related to problematic smartphone use. Computers in Human Behavior, 63, 509516.

22. Elhai, J. D., Levine, J. C. \& Hall, B. J. (2019). The relationship between anxiety symptom severity and problematic smartphone use: A review of the literature and conceptual frameworks. Journal of Anxiety Disorders, 62, 45-52. https://doi.org/10.1016/j. janxdis.2018.11.005.

23. Elhaia, J. D., Yanga, H., Fanga, J., Baia, X., Hall, B. J. (2020). Depression and anxiety symptoms are related to problematic smartphone use severity in Chinese young adults: Fear of missing out as a mediator. Addictive Behaviors, 101, 105962 https://doi.org/10.1016/j.addbeh.2019.04.020

24. Fox, J. \& Moreland, J. J. (2015). The dark side of social networking sites: An exploration of the relational and psychological stressors associated with Facebook use and affordances. Computers in Human Behavior, 45, 168-176.

25. Gokler, M. E., Aydin, R., Unal, E., \& Metintas, S. (2016). Determining validity and reliability of Turkish version of Fear of Missing out Scale. Anadolu Psikiyatri Dergisi, 17(1), 53-59.

26. Herrero, J., Urueña, A., Torres, A., Hidalgo, A. (2019). Socially connected but still isolated: Smartphone addiction decreases social support over time. Social Science Computer Review, 37, 73-88.

27. Hong, F. Y., Chiu, S. I., \& Huang, D. H. (2012). A model of the relationship between psychological characteristics, mobile phone addiction and use of mobile phones by Taiwanese university female 
students. Computers in Human Behavior, 28, 2152-2159. doi:10.1016/j. chb.2012.06.020

28. Haugi, S., Castro, R.P., Kwon, M., Filler, A., Kowatsch, T., \& Schaub, M. P. (2015). Smartphone use and smartphone addiction among young people in Switzerland. Journal of Behavioral Addictions, 4(4), 299307 doi: 10.1556/2006.4.2015.037

29. Habke, A. M., Hewitt, P. L., Norton, G. R. \& Asmundson, G. (1997). The social phobia and social interaction anxiety scales: an exploration of the dimensions of social anxiety and sex differences in structure and relations with pathology. Journal of Psychopathology and Behavioral Assessment, 19(1), 21-39.

30. Hawi, N. S. \& Samaha, M. (2017a). Relationships among smartphone addiction, anxiety, and family relations. Behavior \& Information Technology, 36(10), 1046-1052. https://doi.org/10.1080/0144929X.2017.1336254

31. Hawi, N. S. \& Samaha, M. (2017b). The Relations among Social Media Addiction, Self-Esteem, and Life Satisfaction in University Students. Social Science Computer Review, 35(5), 576-586. doi: 10.1177/0894439316660340

32. Hetz, P. R., Dawson, C. L., \& Cullen, T. A. (2015). Social media use and the fear of missing out (FoMO) while studying abroad. Journal of Research on Technology in Education, 47(4), 259-272, doi: 10.1080/15391523.2015.1080585

33. Hirsch, C. R., Clark, D. M., Mathews, A., \& Williams, R. (2003). Selfimages play a causal role in social phobia. Behavior Research and Therapy, 41(8), 909-921. doi:10. 1016/S0005-7967(02)00103-1

34. Hu, L. \& Bentler, P. (1999). Cutoff criteria for fit indices in covariance structure analysis: conventional criteria versus new alternatives. Structural Equation Modeling, 6, 1-55.

35. Jeong, S., Kim, H. J., Yum, J., \& Hwang, Y. (2016). What type of content are smartphone users addicted to?: SNS vs. games. Computers in Human Behavior, 54, 10-17.

36. Kawabe, K., Horiuchi, F., Ochi, M., Oka, Y. \& Ueno, S. I. (2016). Internet addiction: Prevalence and relation with mental states in adolescents. Psychiatry and Clinical Neurosciences, 70, 405-412. doi:10.1111/pcn.12402

37. Kashdan, T. B. (2004). The neglected relationship between social interaction anxiety and hedonic deficits: differentiation from depressive symptoms. Anxiety Disorders, 18, 719-730.

38. Kilic, S. (2016). Cronbach's alpha reliability coefficient. Journal of Mood Disorders (JMOOD), 6(1), 47-48. 
39. Kim, K. (2013). Association between Internet overuse and aggression in Korean adolescents. Pediatrics International, 55(6), 703-709. doi: 10.1111/ped.12171

40. Kim, D., Lee, Y., Lee, J., Nam, J. K. \& Chung, Y. (2014). Development of Korean Smartphone Addiction Proneness Scale for Youth. PLoS ONE, 9(5), 1-8. https ://doi.org/10.1371/journal.pone.00979 20.

41. Kimbrel, N. A., Mitchell, J. T., \& Nelson-Gray, R. O. (2010). An examination of the relationship between behavioral approach system (BAS) sensitivity and social interaction anxiety. Journal of Anxiety Disorders, 24, 372-378.

42. Kline, R. B. (2011). Convergence of structural equation modeling and multilevel modeling (Edited Malcolm Williams \& W. Paul Vogt) In The SAGE Handbook of Innovation in Social Research Methods. https://dx.doi.org/10.4135/9781446268261.n31

43. Konan, N., Durmus, E., Turkoglu, D. \& Agıroglu-Bakir, A. (2018). How is smartphone addiction related to interaction anxiety of prospective teachers? Education Science, 8, 186. doi:10.3390/educsci8040186

44. Konan, N. \& Celik, O. T. (2019). The mediator role of interaction anxiety in the relationship between social support perception and smartphone addiction. Journal of Education and Future, 15, 63-75.

45. Kuss, D. J. \& Griffiths, M. D. (2011). Online social networking and addiction- a review of the psychological literature. International Journal of Environmental Research and Public Health, 8(9), 35283552. doi:10.3390/ijerph8093528

46. Kuss, D. J., Griffiths, M. D., Karila, L. \& Billieux, J. (2014). Internet addiction: a systematic review of epidemiological research for the last decade. Current Pharmaceutical Design, 20 (25), 4026-4052.

47. Kwon, M., Lee, J. Y., Won, W. Y., Park, J. W., Min, J. A., Hahn, C., Gu, X., Choi, J. H., \& Kim, D. J. (2013). Development and validation of a smartphone addiction scale (SAS). PLoS ONE, 8(2), e56936.

48. Laconi, S., Tricard, N., \& Chabrol, H. (2015). Differences between specific and generalized problematic Internet uses according to gender, age, time spent online and psychopathological symptoms. Computers in Human Behavior, 48, 236-244, http://dx.doi.org/10.1016Zj.chb.2015.02.006.

49. Leary M. R. \& Kowalski, R. M. (1993). The interaction anxiousness scale: Construct and criterion-related validity. Journal of Personality Assessment, 61 (1), 136146. 
50. Lee, Y. K., Chang, C. T., Lin, Y., \& Cheng, Z. H. (2014). The dark side of smartphone usage: Psychological traits, compulsive behavior and technostress. Computer Human. Behavior, 31, 373-383.

51. Lyvers, M., Hanigan, C. \& Thorberg, F. A. (2018). Social interaction anxiety, alexithymia, and drinking motives in Australian university students. Journal of Psychoactive Drugs, 50(5), 402-410, doi: 10.1080/02791072.2018.1517228

52. Lopez-Fernandez, O. (2017). Short version of the Smartphone Addiction Scale adapted to Spanish and French: Towards a crosscultural research in problematic mobile phone use. Addictive behaviors, 64

275-280. http://dx.doi.org/10.1016/j.addbeh.2015.11.013

53. Mattick, R. P., \& Clarke, J. C. (1998). Development and validation of measures of social phobia scrutiny fear and social interaction anxiety. Behavior Research and Therapy, 36, 455-470.

54. Mohammadi, S., Valinejadi, A., Saman, J. A., Karimpour, H., Kaivanfar, M. Safaeipour, M., Mohammadi, A., \& Kawyannejad, R. (2018). Assessment of addiction to internet, smartphone and social networks among students of medical sciences: a cross sectional study. Electron $J$ Gen Med, $15 \quad$ (4), em35. https://doi.org/10.29333/ejgm/85685

55. Mok, J. Y., Choi, S. W., Kim, D. J., Choi, J. S., Lee, J., Ahn, H., Choi, E. J., \& Song, W. Y. (2014). Latent class analysis on internet and smartphone addiction in college students. Neuropsychiatric Disease and Treatment 10, 817-128. doi:10.2147/NDT.S59293.

56. Noyan, C. O., Enez-Darçın, A., Nurmedov, S., Yilmaz, O. \& Dilbaz, N. (2015). Validity and reliability of the Turkish version of the smartphone addiction scale-short version among university students. Anadolu Psikiyatri Dergisi, 16 (1), 73-81.

57. Oberst, U., Wegmann, E., Stodt, B., Brand, M., \& Chamarro, A. (2017). Negative consequences from heavy social networking in adolescents: the mediating role of fear of missing out. Journal of Adolescence, 55, 51-60.

58. O'Reilly, M. (1996). Internet addiction: a new disorder enters the medical lexicon. Canadian Medical Association Journal, 154(12), 1882-1883.

59. Park, B. W., \& Lee, K. C. (2011). The effect of users' characteristics and experiential factors on the compulsive usage of the smartphone. Ubiquitous Computing and Multimedia Applications, 151, 438-446.

60. Pierce, T. (2009). Social anxiety and technology: Face-to-face communication versus technological communication among teens. Computers in Human Behavior, 25, 1367-1372. 
61. Przybylski, A.K., Murayama, K., DeHaan, C. R., \& Gladwell, V. (2013). Motivational, emotional, and behavioral correlates of fear of missing out. Computers in Human Behavior, 29(4), 1841-1848.

62. Reagle, J. (2015). Following the Joneses: FOMO and conspicuous sociality. First Monday, 20(10). https://doi.org/10.5210/fm.v20i10.6064

63. Samaha, M., \& Hawi, N. S. (2016). Relationships among smartphone addiction, stress, academic performance, and satisfaction with life. Computers in Human Behavior, 57, 321-325.

64. Shin, J. H., \& Jang, M. (2016). Effect of group sandplay therapy to be addicted youth's addiction levels and anxiety. Journal of Symbols \& Sandplay Therapy, 7(1), 39-55. doi:10.12964/ jsst.160002

65. Tanaka, J. S., \& Huba, G. J. (1985). A fit index for covariance structure models under arbitrary GLS estimation. British Journal of Mathematical and Statistical Psychology, 38, 197-201.

66. Thomsen, K. R., Callesen, M. B., Hesse, M., Kvamme, T. L., Pedersen, M. M., Pedersen, M. U., \& Voon, V. (2018). Impulsivity traits and addiction-related behaviors in youth. Journal of Behavioral Addictions, 7(2), 317-330.

67. Wegmanna, E., Oberst, U., Stodt, B., \& Branda, M. (2017). Onlinespecific fear of missing out and Internet-use expectancies contribute to symptoms of Internet-communication disorder. Addictive Behaviors Reports, 5, 33-42.

68. Wolniewicz, C. A., Tiamiyu, M. F., Weeks, J. W., \& Elhai, J. D. (2018). Problematic smartphone use and relations with negative affect, fear of missing out, and fear of negative and positive evaluation. Psychiatry Research, 262, 618-623. 